\title{
Evaluation of the Ability Family Planning Center Officers in the Youth Counseling Information Center Program in South Buru Regency
}

\author{
Samna Detek ${ }^{1}$, Sukri Palutturi², Muhammad Alwy Arifin², \\ Amran Razak ${ }^{2}$, Arsunan Arsin ${ }^{3}$, Nurhayani², Anwar Mallongi ${ }^{4}$ \\ ${ }^{1}$ Magister Student, Program Departement of Health Administration and Policy, Public Health Hasanuddin \\ University, ${ }^{2}$ Professor of Departement of Health Administration and Policy, Public Health Hasanuddin University, \\ ${ }^{3}$ Professor of Departement of Epidemiology, Public Health Hasanuddin University, ${ }^{4}$ Professor of Department \\ Departement of Environmental health, Faculty of Public Health, Hasanuddin University
}

\begin{abstract}
Adolescent problems are very complex problems ranging from large numbers to health risk problems. The purpose of this study to evaluate the ability of Family Planning Center officers in the Youth Counseling Information Center Program in South Buru Regency. This type of research is qualitative analysis. The data collection techniques in this study are indepth interviews and document studies. The informants in this study were divided into 2 sources, namely the key informants in this study as many as 2 people, namely 1 Head of Population control and Family Planning, 1 head of the Program Section of the Youth Counseling Center of South Buru Regency and the usual informant in this study as many as 7 people namely 6 Heads of Family Planning Hall in each sub-district in South Buru Regency, 1 person chairman of youth counseling information center at SMAN 1 Namrole as ambassador representative of Youth Counseling Information Center. The results showed that the ability of youth counseling information center officers in carrying out the Youth Counseling Information Center program in South Buru District is sufficient. To improve the skills and skills of youth counseling information center officers, there is regular training every year at both the district and provincial level. Not every sub-district can participate in training because there is never another invitation to attend training in the district or in the province, thus requiring to seek literature and study selftaught. The government is expected to realize the consistency of training (refreshing) for each district hall officer, centered in the district or in BKKBN Province with professional coaches by inviting all district hall officers so that each officer has the same ability and knowledge
\end{abstract}

Keywords: Officer capability, Program, Counseling Information, adolescents,Buru South.

\section{Introduction}

Adolescence is one of the fastest phases of human development, according to the World Health Organization

\author{
Correspondence Author: \\ Samna Detek \\ Magister Student, Program Departement of Health \\ Administration and Policy, Public Health Hasanuddin \\ University \\ e-mail: samnadetek2323@gmail.com
}

adolescents are those aged 10-19. Adolescent problems are very complex problems ranging from large numbers to problems around adolescent reproductive health. The number of teenagers in the world as of January 2018 is about 1.2 billion people ${ }^{1}$. Globally the leading causes of death among adolescents are road injuries, HIV, suicide, lower respiratory tract infections, and interpersonal violence $^{2-3}$. The problem of adolescents is also a fairly complex problem especially in urban are Adolescents face specific health risks, especially those related to reproduction and sexuality. $11 \%$ of all births and $14 \%$ of maternal deaths worldwide occur in women aged 15 to 19 , of which $95 \%$ of teen births occur in developing 
countries ${ }^{1}$. Poor, marginalized, and life-losing youth suffer the highest burden of disease, for example homeless teenagers face a higher risk of HIV infection. Adolescents with disabilities are particularly vulnerable to sexual harassment and the result is unplanned pregnancies and HIV and other sexually transmitted. ${ }^{9-10}$

Based on Data on Indonesia Population Projection 2000-2025, the proportion of the population of adolescents aged 10-19 years in 2010 was about $18.3 \%$ of the total population or about 43 million people ${ }^{11}$. The condition of teenagers in Indonesia is currently very concerning. In 2017, the percentage of women and men who smoked before the age of 13 was higher in the 15 19 age group compared to 20-24 years of age, where $27 \%$ of women aged $15-19$ had started smoking before the age of 13 and $22 \%$ in women aged $20-24.70 \%$ of men and $58 \%$ of women started drinking alcohol in the 15-19 age group.

However, it found $2 \%$ of men and $6 \%$ of women started drinking alcohol under the age of 10 . Most women (80\%) and men (84\%) $45 \%$ of women and $44 \%$ of men start dating between the ages of $15-17$. Teenage courtship behavior showed that as many as $8 \%$ of men and $2 \%$ of women reported having sexual intercourse, arguing that $47 \%$ loved each other, $30 \%$ were curious/ curious, $16 \%$ just happened and 3\% were forced and influenced by friends. Among women and men who had had sexual intercourse before pre-marriage, 59\% of women and $74 \%$ of men reported starting to have sexual intercourse first at the age of 15-19 where the highest percentage occurred at the age of 17 both male and female. $^{12}$

The way to know the performance of the officer in dealing with the problem of the implementation of a program can be done by evaluating the performance of the officer, in the application process or at the end of the application. Performance evaluation is an activity that management does to assess the performance of employees in an organization or company by comparing job descriptions that have been set before ${ }^{13-14}$. The purpose of this research is to evaluate the ability of family planning center officers in the youth counseling information center program in South Buru Regency

\section{Materials and Method}

The type of research used is a qualitative research method. The data collection techniques in this study are indepth interviews and document studies. The informants in this study were divided into 2 sources, namely the key informants in this study as many as 2 people, namely 1 Head of Population control and Family Planning, 1 head of the Program Section of the Youth Counseling Center of South Buru Regency and the usual informant in this study as many as 7 people namely 6 Heads of Family Planning Hall in each district in Kab. Buru Selatan, 1 person chairman of youth counseling information center at SMAN 1 Namrole as ambassador representative of Youth Counseling Information Center.

\section{Results}

The evaluation of the capabilities of the officers referred to in this study is an explanation of the Youth Counseling Information Center program, activities that are already underway in the Family Planning Center related to the Youth Counseling Information Center program, views on the ability of youth counseling information center officers in the Family Planning Center, things that have been taken in improving the ability and skills of youth counseling information center officers in the Family Planning Center.

Based on the results of interviews with informants, it is known that some informants said that the ability of youth counseling center officers is in line with expectations because officers have work experience in the Central Embassy beforehand so have a good understanding of the Youth Counseling Information Center program as well as the access to training. While some informants said it was not as expected because it had never previously socialized to the community so in the beginning it was constrained in communication. Here's an excerpt from the interview:

“... Family Planning Hall, I must know there is only one family planning doctor Outag Planning Center who is in charge in Leksula Sub-District (IbuLamatokang), the other personnel comes from contractual midwives, civil servants are only a few who come in, so speaking residency (Youth Counseling information center), it's all empty, only Lamatokang's mother understands the concept of BKKBN. In terms of a lot of energy, but $\mathrm{hr}$ skills are dilemma, I claim to be weak as a pioneer, so from the bottom all look weak." (KW, 55, Head of Population Control and South Buru)

“... Not fully formed Ambassadors have the ability because there must be maximum training before they counsel personally to their friends or classmates. Honestly gendre action district has never katong 
ambassador involved, since I have two years working because it has no transportation cost to the expensive district. Giving certificates to ambassadors, beta submit with their teachers, for the purposes of documentation per monthly report, although the ambassadors I form have not been quite active but they are slowly not as expected." (AW, 31, Head of Family Planning Center of Kepala Madan Sub-District)

“... Of all family planning field counseling personnel in Namrole sub-district two workers consist of Midwives and Nurses, Wesama Sub-District one midwife, Leksula sub-district one midwife, FenaFafan sub-midwife, One nurse in Madan Head Sub-district, and Ambalau submidwife. And only one pure BKKBN power one person from Leksula. Namrole's best evaluation results, only Namrole has Gendre Ambassadors, for the future plan to be planned to select Gendre Ambassadors in each subdistrict." (NP, 36, Head of Program Section of South Buru District Youth Counseling Information Center) Other informants said that some youth counseling information center officers were in line with expectations because the ambassador chosen was an accomplished student and often participated in activities in the field. Here's an interview excerpt:

“... officer's ability has been slightly in line with expected because all the Youth Counseling Information Center groups that we have shaped all of our achievement categories are not inecuated, so every activity that will be carried out is all involved in the management of their respective work areas until cooperation with cross-sector even they are involved." (RM, 25, Head of Namrole District Family Planning Hall)

"... Midwives are used to going down in the community if called to get involved, as last month involved the inauguration of Family Village planning on the beach of the village wali." (AN, 15, Chairman of SMAN 1 Namrole Youth Counseling Information Center)

Based on the results of an in-depth interview between the head of population control and Family Planning, The head of the Youth Counseling Information Center program and head of the Family Planning Center, Chief Madan, said that the ability of youth counseling information center officers in general is still not as expected because some districts are still constrained by access and funding to improve the capabilities of officers, thus requiring 5 Heads of Family Counseling center planning to slowly spur their ability to achieve the expected output, despite equipting themselves with limited literature, but they can form a group of Youth Counseling Information Centers, consisting of high-achieving teenagers, despite only running in 3 subdistricts.

Based on the results of interviews with informants, it is known that in improving the ability and skills of youth counseling information center officers, there is training of Youth Counseling information center or action genre district and provincial level. Training is usually filled by speakers from BKKBN District/Provincial Training Hall through lecture method, q\&amp;A and games. The targets in this study were youth counseling information center officers to increase knowledge and awareness through the Adolescent Counseling information center on adolescent reproductive health. Here's an excerpt from the interview:

“... Training for all staff of the Family Planning Center or Clinic is very rare, so learn more self-taught." (KW, 55, Head of Population control and family planning of South Buru Regency)

“... Human Resources Counseling field family planning should understand the program so it should love a lot of training from the previous year because this (Youth Counseling information center), must understand this program tiered, advocacy, counseling, and know the truth of the Youth Counseling information center." (NP, 36, Head of Program Section of South Buru District Youth Counseling Information Center)

“... During 2019 there has never been beta training, except 2018 followed 3 trainings in the province, whereas many additional programs require self-study for additional programs related to youth counseling and $\mathrm{kb}$ information centers." (AW, 31, Head of Family Planning Center of KepalaMadan Sub-District)

“... Training needs to be (very) necessary, there is the addition of new programs, field technicalities that need to be learned to, so that we can channel it to that community. If during 2019 never participated in training, only in 2018 training in Ambon three times participated." (YS, 30, Head of Family Planning Center of FenaFafan Sub-District)

“... Skill improvement training so far only in 2018, but sometimes I go to BKKBN Province to participate in training because for the district level has not been penah done, as the only staff in the family planning hall 
leksula sub-district completed the program well because it was assisted by the midwife coordinator of leksula health center." (VL, 55, Head of Family Planning Center Leksula Sub-District)

"... The challenge of the beginning is just, because it is still learning from the field and many helped to see updates from youtube or google. The usual material is prepared about reproductive health, namely knowing the characteristics of puberty, knowing the risk of pregnancy with one sex, and knowledge of Sexually Transmitted Diseases (STDs)." (AN, 15, Chairman of SMAN 1 Namrole Youth Counseling Information Center)

Overall, the ability of youth counseling information center officers in South Buru Regency is sufficient. All eight informants already have a common understanding of the Youth Counseling Information Center program. Youth Counseling Information Center activities have been conducted in each school and village and each already has a group of Youth Counseling information centers although some informants say that they are unable to reach each village to conduct youth counseling information centers because access to locations is quite difficult (sea). To improve the skills and skills of youth counseling information center officers, it should be organized in the planning of district activities but not done. Similarly, the province does not invite participants from all halls in South Buru Regency because there is no proposal from the district. The lack of planning and supervision from province to district and district to each of its halls led to various training programs not running as they should.

\section{Discussion}

There are three groups of variables that affect performance and behavior, one of which is individual variables, which include abilities and skills where ability and skill are the main factors that affect individual performance ${ }^{15-21}$. The ability of officers is seen to assess the extent to which carrying out various tasks in a job is possible and one can get the job well done ${ }^{20}$. o improve their skills and skills, Youth Counseling Information Center officers are given training/action genre districts and provinces every year.although only leksula sub-district family planning center officers have been training in the province since 2019 . While other hall officers never participated in youth counseling information center training, because there was never any more invitation to attend training in the district or in the province, thus requiring to seek literature and study selftaught.

This is certainly an evaluation for the officers of the Provincial or District Family Planning Center so that in the future each officer of the District Family Planning Hall gets an invitation to participate in training in the District and Province so that all officers of the District Family Planning Hall get the same opportunity to improve the skills and skills regarding the Youth Counseling Information Center program

Research conducted by Salla et al shows the ability of officers not to be able and skilled in running the program and some officers do not yet have a registration certificate as a guarantee of the quality of health workers ${ }^{22-23}$. Human resource quality improvement activities have also been carried out by BPPKB Banyuwangi Regency by holding training for educators or peer counselors, but the training is still not optimal karen not implemented regularly ${ }^{24-25}$.

Inadequate resources will create a barrier to policy implementation ${ }^{26-30}$.outh life is a very decisive life for their next future life. The activities that have been carried out by youth counseling information center officers in South Buru District are (1) establish a counseling information center in the school environment to provide information services and counseling about 8 Family Functions, Marriage Age Maturity, TRIAD KRR, Life Skills, Gender, Advocacy and Communication information and education. (2) Promote and socialize the Youth Counseling Information Center in the community to introduce the existence of youth counseling information center to all relevant parties in order to expand access and development of support and network of youth counseling information centers. (3) Prepare and empower human resources managers of youth counseling information centers to prepare and empower human resources both for the newly grown youth counseling information center and to replace the no longer active human resources with various causes (regeneration) for the continuity of youth counseling information centers. (4) Conduct administration, recording and reporting to improve administrative order and document activities in the management and service provided by the youth counseling information center, including human resources, facilities, infrastructure and method. 


\section{Conclusion}

This study concluded that the ability of youth counseling information center officers in carrying out the Program of Youth Counseling Information Center in South Buru District is sufficient. To improve the skills and skills of youth counseling information center officers, there is regular training every year at both the district and provincial level. Not every sub-district can participate in training because there is never another invitation to attend training in the district or in the province, thus requiring to seek literature and study self-taught. The government is expected to realize the consistency of training (refreshing) for each district hall officer, centered in the district or in BKKBN Province with professional trainers by inviting all district hall officers so that each officer has the same skills and knowledge.

Ethical Clearance: Taken from University ethical clearance committee

Source of Funding: Self

Conflict of Interest: Nil.

\section{References}

1. WHO. World Health Statistic Report 2018. Geneva: World Health Organization;2018.

2. Adam A, Badwi A, Palutturi S. Analysis of Factors Associated with Self-Stigma (PLHIV) on the HIV and AIDS Incidencein Jongaya Positive Care Supporting Group of Makassar City. Indian Journal of Public Health Research \& Development. 2019;10(11).

3. Darmawansyah SR, Muh S, Balqis AA. The analysis of factors affecting the use of VCT service for high-risk group infected with HIV/AIDS in Makassar. Int J Res Heal Sci. 2014;2:5.

4. Palutturi S, Chu C, Moon JY, Nam EW. A Comparative Study on Healthy City Capacity Mapping: Indonesia and Korea. The Social Sciences. 2015;10(6):848-854.

5. Palutturi S, Arifin MA. Re-Standardization Makassar Healthy City based on Local Needs. Indian Journal of Public Health Research \& Development. 2019;10(2).

6. Palutturi S. Healthy Cities Implementation in Indonesia: Challenges and determinants of successful partnership. 2013.
7. Palutturi S. Healthy Cities: Global Concepts, Local Implementation for Indonesia. Yogyakarta: Pustaka Pelajar; 2018.

8. Palutturi S, Zulkifli A, Syam A, et al. The Key Challenges and Recommendations for Healthy Cities Implementation of North Kolaka, Indonesia. Indian Journal of Public Health Research \& Development. 2017;8(2).

9. Busza JR, Balakireva OM, Teltschik A, et al. Streetbased adolescents at high risk of HIV in Ukraine. J Epidemiol Community Health. 2011;65(12):11661170.

10. Suswani A, Arsin AA, Amiruddin R, Syafar M, Palutturi S. Factors related quality of life among people living with HIV and AIDS in Bulukumba. International Journal of Community Medicine and Public Health. 2018;5(8):3227-3231.

11. Kemenkes RI. Pedoman Standar Nasional Pelayanan Kesehatan Peduli Remaja (PKPR). Jakarta: Kementerian Kesehatan Republik Indonesia;2014.

12. BKKBN. Survei Demografi dan Kesehatan Indonesia: Perkawinan, Fertilitas dan Keluarga Nerencana. Jakarta: Badan Kependudukan dan Keluarga Berencana Nasional;2018.

13. Profil Dinkes. Pengendalian Penduduk dan KB Kab. Buru Selatan. Kabupaten Buru Selatan: Dinas Kesehatah;2019.

14. Mangilep AU, Paluttui S, Angraeni R, Noor NB. Pelatihan, Pendamping dan Evaluasi Peningkatan Kapasitas Masyarakat di Tingkat Kelurahan dalam Mewujudkan Lorong Sehat Makassar. JURNAL TEPAT: Applied Technology Journal for Community Engagement and Services. 2019;2(1):78-83.

15. Jufri N, Razak A, Brasit N. PENGARUH FAKTOR ORGANISASI TERHADAP KINERJA PETUGAS IMUNISASI DALAM PENCAPAIAN UNIVERSAL CHILD IMMUNIZATION (UCI) KOTA BAUBAU. Idrus Qaimuddin. 2019;1(1):8190.

16. Ningsih NA, Indar AR. Analisis Hubungan PrinsipPrinsip Good Governance dengan Kinerja Pegawai di Dinas Kesehatan Kabupaten Luwu Timur. Universitas Hassanudin Makassar. 2011.

17. Palutturi S. Determinan Kinerja Bidan di Puskesmas Tahun 2006. Jurnal Manajemen Pelayanan Kesehatan. 2007;10(04). 
18. Abdullah MT, Darmawansyah D, Hafsah H. Pengaruh Variabel Individu, Psikologis dan Organisasi terhadap Kinerja Bidan dalam Pertolongan Persalinan di Rskd Ibu dan Anak Siti Fatimah Makassar Tahun 2013. Jurnal Administrasi dan Kebijakan Kesehatan Indonesia.3(01):8237.

19. Muin H, Palutturi S, Sirajuddin S, Mallongi A, Syam A. User's satisfaction about the use of simrs performance of outpatient units in nene mallomo hospital sidenreng rappang regency. Enfermería Clínica. 2020;30:388-391.

20. Nurdin R, Indar D. Pengaruh Gaya Kepemimpinan Dan Kepuasan Kerja Terhadap Kinerja Pegawai Di RSUD Namlea Kabupaten Buru Provinsi Maluku. Jurnal. 2013.

21. Abdullah R, Darmawansyah D, Sabarulin S. Faktor yang Mempengaruhi Kinerja Perawat dalam Mendokumentasikan Asuhan Keperawatan di Rumah Sakit Woodward Palu. Jurnal Administrasi dan Kebijakan Kesehatan Indonesia. 2013;2(03):8224.

22. Oonsopiah. Kebijakan Pelaksanaan Pusat Informasi Konseling Remaja (PIK R) Berbasis Sekolah di Karawang. Health Science Growth (HSG) Journal. 2017;2(1):47-62.

23. Salla ST, Zuklifli A, Palutturi S. Kinerja Dinas Kesehatan Kabupaten Mamberamo Tengah Pada Program Kesehatan Ibu Dan Anak. Jurnal Kesehatan Masyarakat Maritim. 2020;1(1):63-72.

24. Ibaadillah AA, Samtyaningsih D. EVALUASI PELAKSANAAN PIK R (PUSAT INFORMASI DAN KONSELING KESEHATANREMAJA) DI KABUPATEN BANYUWANGI. Prosiding. 2017;7(1).
25. Rusydi AR, Palutturi S, Noor NB, Pasinringi SA. The comparison of good corporate governance on human resources performance in regional general hospital of Labuang Baji and Ibnu Sina hospital Makassar, South Sulawesi. Enfermería Clínica. 2020;30:482-486.

26. Palutturi S, Rutherford S, Davey P, Chu C. The Challenges and the Needs of Partnership in the Implementation of Healthy Cities in Indonesia: A Case Study of Makassar. Journal of US-China Public Administration. 2015;12(6):469-476.

27. Naiem MF, Indar I, Indar I. Faktor yang berhubungan dengan kelengkapan rekam medis di RSUD H. Padjonga Dg. Ngalle Takalar. Jurnal Administrasi dan Kebijakan Kesehatan Indonesia. 2013;2(02):8259.

28. Amqam, H., Thalib, D., Anwar, D., Sirajuddin, S., Mallongi, A. Human health risk assessment of heavy metals via consumption of fish from Kao Bay. Reviews on Environmental Health. 2020; https://doi.org/10.1515/reveh-2020-0023

29. Agus Erwin Ashari, Irma Muslimin, Anwar Mallongi, The Strategy of Directly Observed Treatment Shortcourse (DOTS) Towards Compliance with Treatment of Tb Lung Patients in Tb Lung Mamuju District Hospital, Indonesia. Sys Rev Pharm 2020;11(1):1185-1187.

30. Gemy Nastity Handayany, Trimaya Cahya Mulat, Eka, Anwar Mallongi. Resistance Test of Some Bacterial Synthetic Calcular Cycinaris Invitro Amoxicillin and Ciprofloxacin Antibiotics in TK II Pelamonia Hospital Makassar, Indonesia. Sys Rev Pharm 2020;11(6):1181-1184 